SUPPORTING INFORMATION

\title{
Chemistry of the Silica Surface: Liquid-Solid Reactions of Silica Gel with Trimethylaluminum
}

\author{
Jianhua Li, Joseph A. DiVerdi, and Gary E. Maciel ${ }^{\star}$ \\ Contribution from the Department of Chemistry, Colorado State University, Fort Collins, \\ Colorado 80523 \\ E-mail: gary.maciel@colostate.edu
}




\section{NMR Spectroscopy}

${ }^{13} \mathrm{C}$ MAS spectra were obtained with a rotor speed of $\sim 3.5 \mathrm{kHz}$. Conditions for cross-polarization (CP) experiments ${ }^{1}$ were ${ }^{1} \mathrm{H}$ RF field strength of $45.5 \mathrm{kHz}$ for $\mathrm{CP}$ contact and decoupling, ${ }^{13} \mathrm{C}$ RF field strength adjusted for maximal signal on a reference sample of solid $\mathrm{HMB}$, a contact time of $5.0 \mathrm{~ms}$ and a recovery time of $3.0 \mathrm{~s}$. Typically, 10000 transients were accumulated. A Lorentzian line broadening of $90 \mathrm{~Hz}$ was applied prior to Fourier transformation. ${ }^{13} \mathrm{C}$ spectra were externally referenced to liquid tetramethylsilane (TMS, $0 \mathrm{ppm}$ ) based on substitution of the secondary reference solid of HMB (16.9 and $132.3 \mathrm{ppm})$.

${ }^{29} \mathrm{Si}$ NMR spectra ${ }^{2-7}$ were obtained with a rotor speed of $3.5 \mathrm{kHz}$. Conditions for cross polarization (CP) experiments were ${ }^{1} \mathrm{H}$ RF field strength of 39.2 and $38.5 \mathrm{kHz}$ for contact and decoupling, respectively, ${ }^{29} \mathrm{Si} \mathrm{RF}$ field strength adjusted for maximal signal on a reference sample of solid untreated silica gel, a contact time of $5.0 \mathrm{~ms}$ and a recovery time of $2.0 \mathrm{~s}$. Typically, 10000 transients were accumulated. A Lorentzian line broadening of $50 \mathrm{~Hz}$ was applied prior to Fourier transformation. ${ }^{29} \mathrm{Si}$ spectra were externally referenced to liquid TMS (0 ppm), based on substitution of the secondary reference solid of TTMSS (-8.1 and $-134.3 \mathrm{ppm})$.

${ }^{27} \mathrm{Al}$ NMR spectra were obtained with a rotor speed of $16.5 \mathrm{kHz}$. Conditions for direct polarization (DP) experiments were ${ }^{27} \mathrm{Al} \mathrm{RF}$ field strength of $95 \mathrm{kHz}$ set using a reference sample of solid alum, and a recovery time of $0.5 \mathrm{~s}$. Typically, 2000 transients were accumulated using a $15^{\circ}$ excitation pulse length. ${ }^{8,9} \mathrm{~A}$ Lorentzian line broadening of $40 \mathrm{~Hz}$ was applied prior to Fourier transformation. ${ }^{27} \mathrm{Al}$ spectra were externally 
referenced to a $1 \mathrm{M} \mathrm{AICl}_{3}$ aqueous solution ( $\left.0 \mathrm{ppm}\right)$, based on substitution of the secondary reference of solid alum $(0.2 \mathrm{ppm})$.

${ }^{1} \mathrm{H}$ NMR spectra were obtained with a rotor speed of $12.5 \mathrm{kHz}$. Conditions for DP experiments were ${ }^{1} \mathrm{H}$ RF field strength of $62.5 \mathrm{kHz}$ using a reference sample of solid PDMS. Typically, 64 transients were accumulated using a $90^{\circ}$ excitation pulse with a recovery time of $30 \mathrm{~s}^{10,11}$ A Lorentzian line broadening of $20 \mathrm{~Hz}$ was applied prior to Fourier transformation. ${ }^{1} \mathrm{H}$ spectra were externally referenced to liquid TMS $(0 \mathrm{ppm})$, based on substitution of the secondary reference of solid PDMS (0 ppm).

\section{Deconvolution of Spectra into Component Parts}

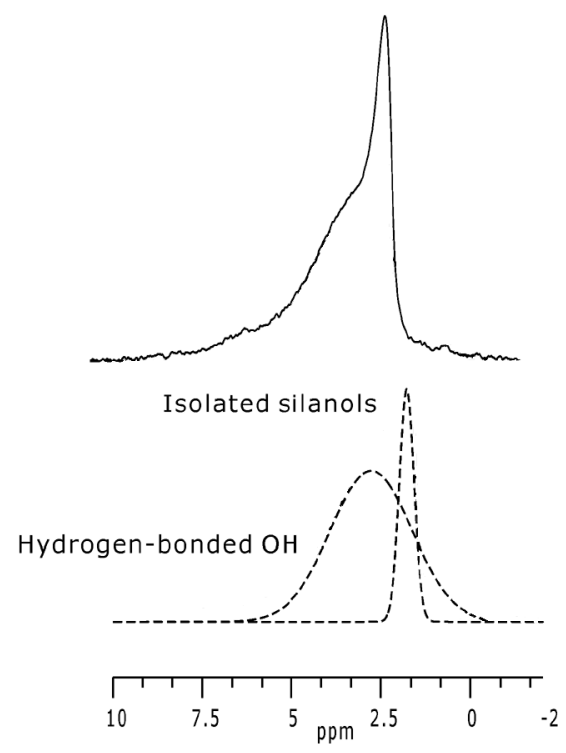

Figure SI-1. ${ }^{1} \mathrm{H}$ MAS spectra of silica gel dried by evacuation at $5 \times 10^{-3}$ Torr and $150 \mathrm{oC}$ for $24 \mathrm{~h}$ and deconvolution into component species. 

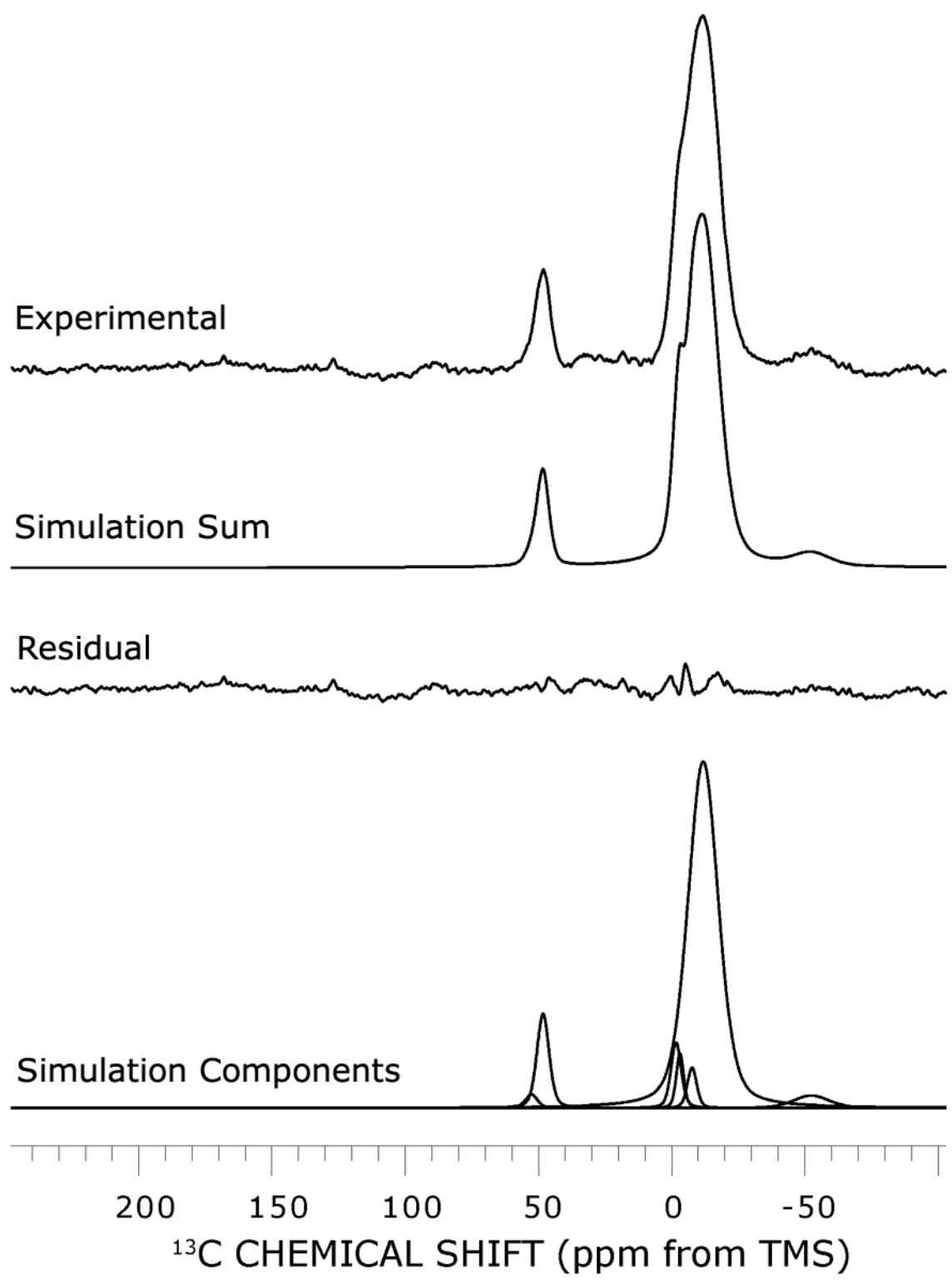

Figure SI-2. ${ }^{3} \mathrm{C}$ NMR spectra of the initial reaction product prepared in toluene: $(\mathrm{A})$ raw experimental spectrum; (B) simulated individual components spectra; (C) simulated spectrum created by summing individual components; (D) Difference spectrum of raw experimental and synthetic spectra. 


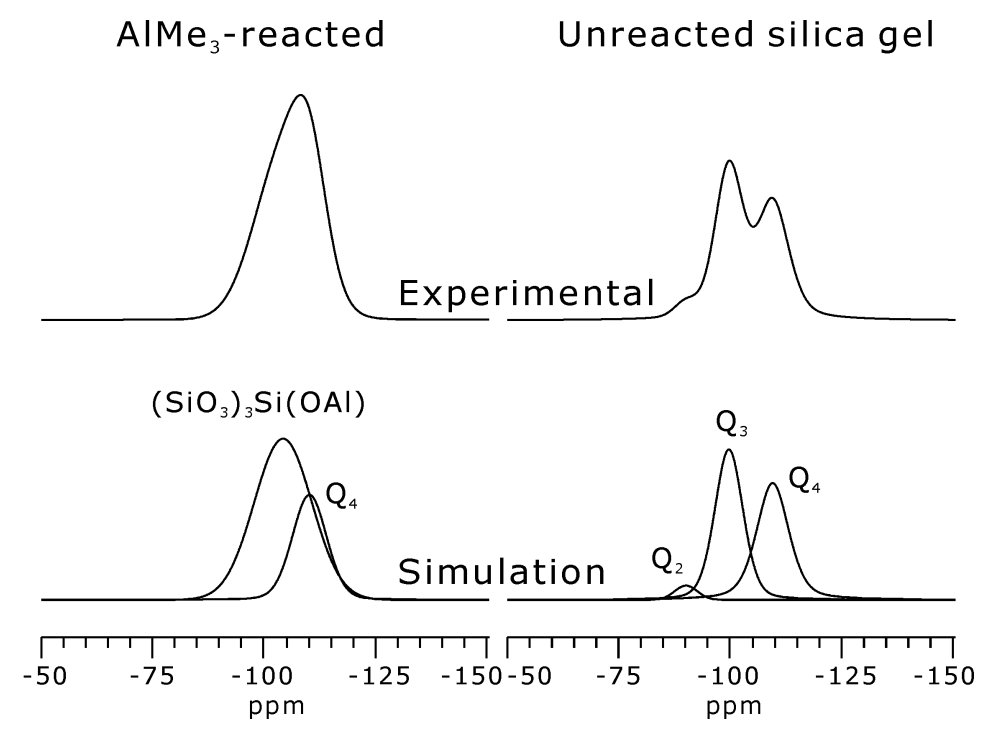

Figure SI-3. ${ }^{29} \mathrm{Si} \mathrm{CP/MAS} \mathrm{spectra} \mathrm{of} \mathrm{dry} \mathrm{silica} \mathrm{gel} \mathrm{and} \mathrm{initial} \mathrm{reaction} \mathrm{product} \mathrm{prepared} \mathrm{in}$ toluene. The raw experimental spectra and simulated individual components spectra are shown above and below, respectively. 
NMR Spectroscopy of Individual Steps in the Reaction Between

Trimethylaluminum and Silica in Toluene

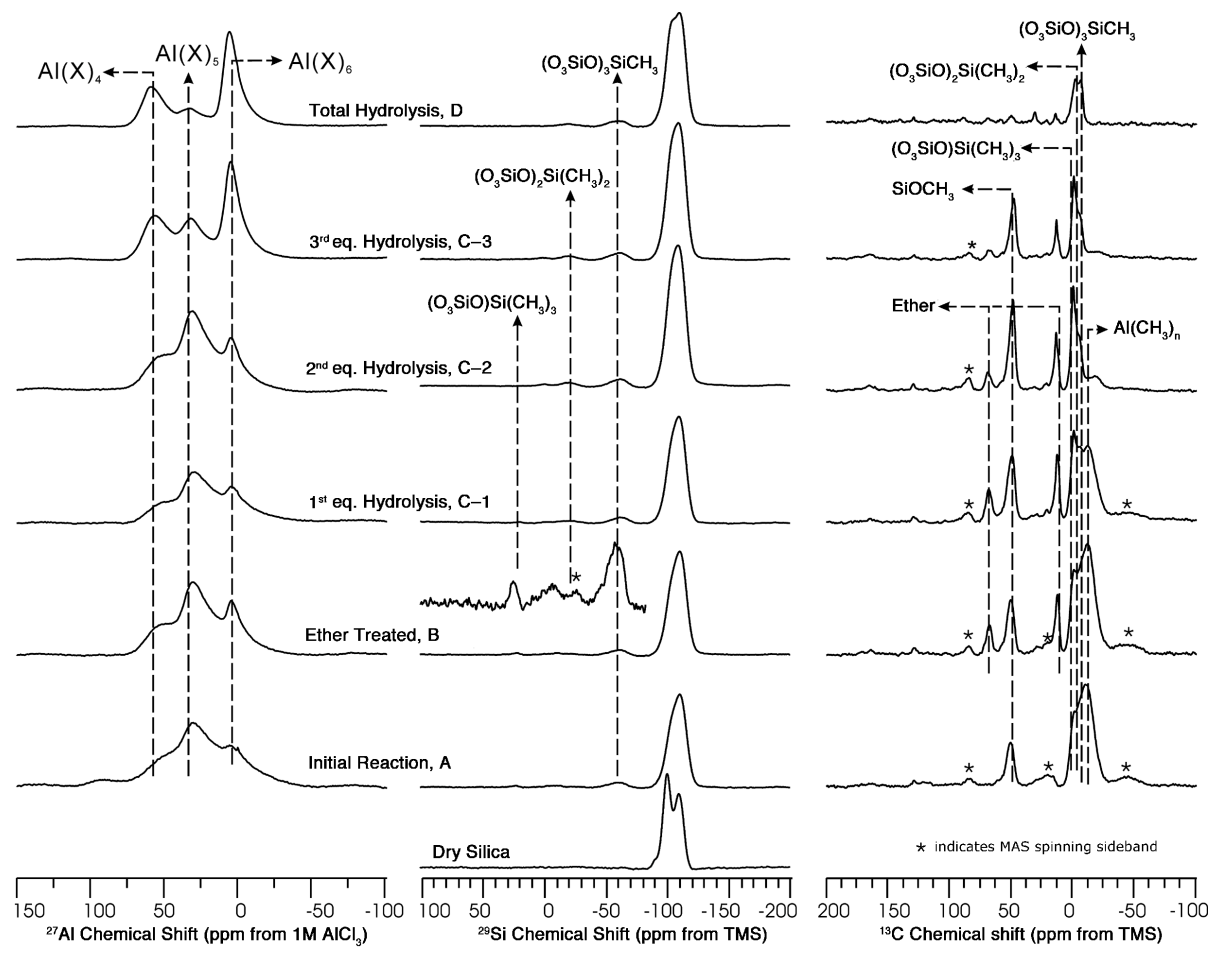

Figure SI-4. ${ }^{27} \mathrm{Al},{ }^{29} \mathrm{Si}$, and ${ }^{13} \mathrm{C}$ MAS spectra of the reaction between trimethylaluminum and dry silica gel in toluene, subsequent treatment with ether, and partial and full hydrolysis steps. 


\section{${ }^{13} \mathrm{C}$ Spin Counting in the Individual Steps in the Reaction Between Trimethylaluminum and Silica in Toluene}

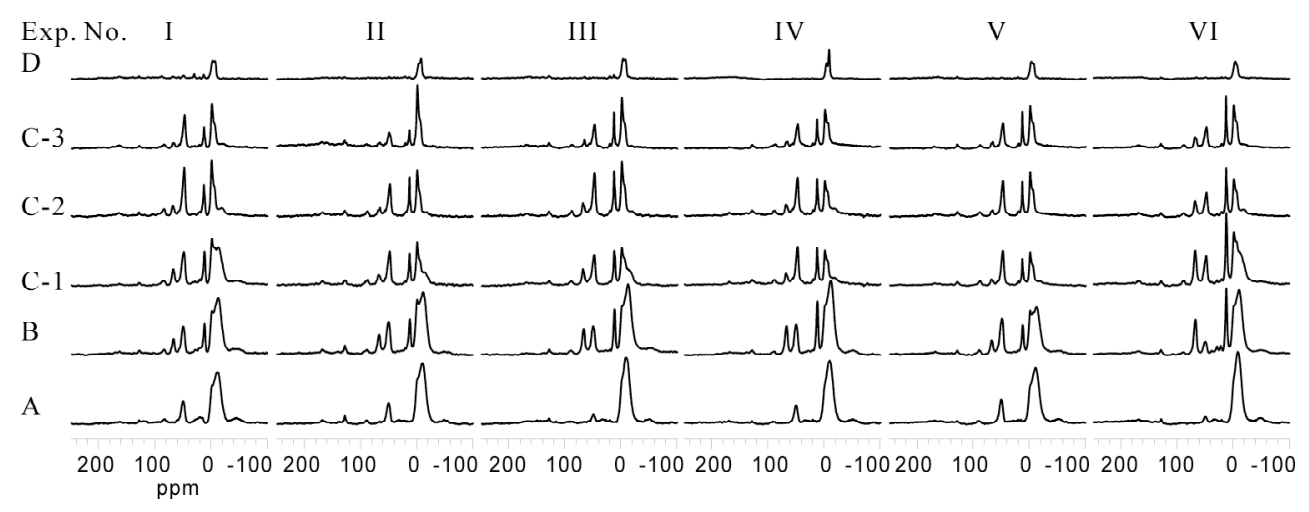

Figure SI-5. ${ }^{13} \mathrm{C}$ MAS spectra of the reaction between trimethylaluminum and dry silica gel in toluene, subsequent treatment with ether, and partial and full hydrolysis steps. The results of six separate reactions are shown.

Table SI-1. $\mathrm{CH}_{4} / \mathrm{CH}_{3}$ counting in replicate reactions in toluene (quantities in mmol).

\begin{tabular}{|c|c|c|c|c|c|c|}
\hline $\mathrm{Si}-\mathrm{OH}^{\mathrm{a}}$ & 62 & 56 & 68 & 64 & 64 & 66 \\
\hline $\begin{array}{c}\mathrm{Al}-\mathrm{Me} \\
\text { added }^{\mathrm{b}}\end{array}$ & 243 & 243 & 243 & 243 & 212 & 212 \\
\hline $\begin{array}{c}\mathrm{CH}_{4} \text { during }^{\mathrm{r}} \\
\text { reaction }^{\mathrm{c}}\end{array}$ & - & 31.7 & 37.8 & 36.8 & 38.6 & 37.3 \\
\hline $\begin{array}{c}\text { Al-Me in } \\
\text { liquid }\end{array}$ & - & 196.6 & 170.7 & 202.6 & 149.0 & 162.4 \\
\hline $\begin{array}{c}\text { Surface Me } \\
\mathrm{e}\end{array}$ & 34.7 & 32.2 & 38.8 & 37.3 & 41.7 & 43.0 \\
\hline Total Me & - & 260 & 247 & 275 & 229 & 233 \\
\hline$\%$ & - & $107.2 \%$ & $101.5 \%$ & $113.2 \%$ & $107.7 \%$ & $109.5 \%$ \\
\hline
\end{tabular}

a. Determined by ${ }^{1} \mathrm{H}$ MAS spin counting. Estimated standard deviation, $2 \%$.

b. Determined by trimethylaluminum added. Estimated standard deviation, 5.7\%.

c. Determined by volume evolution during the reaction.

d. Determined by ${ }^{1} \mathrm{H}$ MAS spin counting in liquid-state NMR.

e. Determined by ${ }^{13} \mathrm{C}$ CP-MAS spin counting.

${ }^{f}$. Estimated standard deviation, $10 \%$ 


\section{${ }^{13} \mathrm{C}$ Spin Counting in the Individual Steps in the Reaction Between Trimethylaluminum and Silica in Cyclohexane}

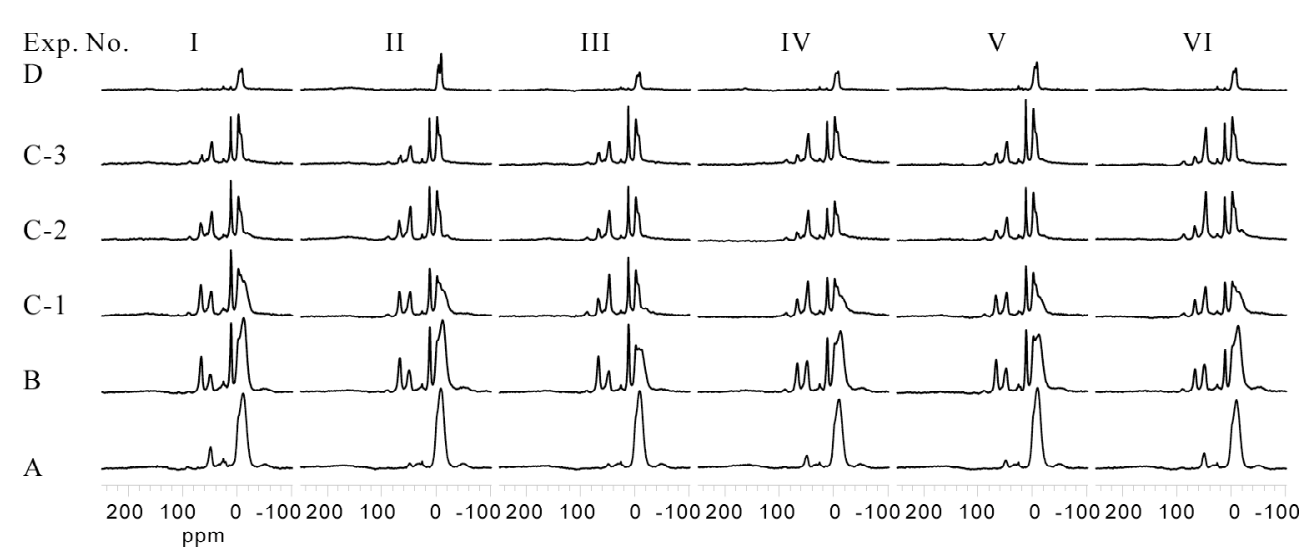

Figure SI-6. ${ }^{13} \mathrm{C}$ MAS spectra of the reaction between trimethylaluminum and dry silica gel in cyclohexane, subsequent treatment with ether, and partial and full hydrolysis steps. The results of six separate reactions are shown.

Table SI-2. $\mathrm{CH}_{4} / \mathrm{CH}_{3}$ counting in replicate reactions in cyclohexane (quantities in $\mathrm{mmol}$ ).

\begin{tabular}{|c|c|c|c|c|c|c|}
\hline $\mathrm{Si}-\mathrm{OH}^{a}$ & 59 & 67 & 66 & 62 & 65 & 66 \\
\hline $\begin{array}{l}\text { Al-Me } \\
\text { added }^{\text {b }}\end{array}$ & 243 & 243 & 212 & 212 & 212 & 212 \\
\hline $\begin{array}{l}\mathrm{CH}_{4} \text { during } \\
\text { reaction }{ }^{\mathrm{C}}\end{array}$ & 34.1 & 38.2 & 42.8 & 36.0 & 38.0 & 36.0 \\
\hline $\begin{array}{l}\text { Al-Me in } \\
\text { liquid }^{d}\end{array}$ & 125.2 & 135.3 & 83.4 & 93.3 & 94.0 & 83.4 \\
\hline $\begin{array}{l}\text { Surface } \\
-\mathrm{Me}^{\mathrm{e}}\end{array}$ & 57.3 & 59.6 & 53.6 & 54.5 & 56.2 & 53.4 \\
\hline Total $\mathrm{Me}^{\mathrm{f}}$ & 217 & 233 & 180 & 184 & 188 & 173 \\
\hline$\%$ & $89.2 \%$ & $96.0 \%$ & $84.6 \%$ & $86.5 \%$ & $88.6 \%$ & $81.3 \%$ \\
\hline
\end{tabular}

a. Determined by ${ }^{1} \mathrm{H}$ MAS spin counting. Estimated standard deviation, $2 \%$.

b. Determined by trimethylaluminum added. Estimated standard deviation, $5.7 \%$.

c. Determined by volume evolution during the reaction.

d. Determined by ${ }^{1} \mathrm{H}$ MAS spin counting in liquid-state NMR.

e. Determined by ${ }^{13} \mathrm{C}$ CP-MAS spin counting.

f. Estimated standard deviation, $10 \%$ 
Estimation of ${ }^{29}$ Si chemical shift of Si-O-Al. It is helpful to consider the $\mathrm{Si}-\mathrm{O}-\mathrm{H} \rightarrow \mathrm{Si}-$ O-Al change in terms of the following two steps: 1) Si-O-H $\rightarrow$ Si-O-Si and 2) Si-O-Si $\rightarrow$ Si-O-Al. For the first step, it is already known that replacing the $(\mathrm{SiO})_{3} \mathrm{Si}(\mathrm{OH})$ moiety by $(\mathrm{SiO})_{3} \mathrm{Si}(\mathrm{OSi})$ changes the ${ }^{29} \mathrm{Si}$ chemical shift of $\mathbf{S i}$ from -99 to $-109 \mathrm{ppm}$. For the second step, the $(\mathrm{SiO})_{4} \mathrm{Si}$ moiety and the $(\mathrm{SiO})_{3} \mathrm{Si}(\mathrm{OAl})$ moiety are the fundamental structural units in zeolite structures and the chemical shifts of $\mathbf{S i}$ in $(\mathrm{SiO})_{4} \mathbf{S i}$ and $(\mathrm{SiO})_{3} \mathrm{Si}(\mathrm{OAl})$ are well studied in the same materials, as represented in Table SI-4. The zeolites from leucite to chabazite in the Table are natural zeolite minerals; and below these are synthetic zeolites. It can seen that the chemical shift change of Si from $(\mathrm{SiO})_{4} \mathrm{Si}$ to $(\mathrm{SiO})_{3} \mathrm{Si}(\mathrm{OAl})$ is fairly consistent, averaging around $+5 \mathrm{ppm}$. On this basis it is reasonable to expect the $\mathrm{Si}-\mathrm{OH} \rightarrow \mathrm{Si}-\mathrm{O}-\mathrm{Al}$ chemical shift change for the species observed in this work to be roughly: $-5 \mathrm{ppm}(-10+5 \mathrm{ppm})$, and the ${ }^{29} \mathrm{Si}$ chemical shift of the $(\mathrm{SiO})_{3} \mathrm{Si}-\mathrm{O}-\mathrm{Al}$ moiety to occur at about:-104 ppm (-99 $\left.-+5 \mathrm{ppm}\right)$. 
Table SI-4. ${ }^{29} \mathrm{Si}$ chemical shifts in zeolites. ${ }^{12-14}$

\begin{tabular}{|c|c|c|c|}
\hline Type of zeolite & $\begin{array}{c}(\mathrm{SiO})_{3} \mathrm{Si}(\mathrm{OAl}) \\
(\mathrm{ppm})\end{array}$ & $\begin{array}{c}(\mathrm{SiO})_{3} \mathrm{Si}(\mathrm{OSil}) \\
(\mathrm{ppm})\end{array}$ & $\begin{array}{c}\text { Chemical Shift } \\
\text { Change }(\mathrm{ppm})\end{array}$ \\
\hline Leucite & -97.4 & -101.0 & +3.6 \\
\hline Heulandite & -99.0 & -1080 & +9.0 \\
\hline Clinoptilolite & -100.5 & -112.8 & +12.3 \\
\hline Stilbite & -101.5 & -108.0 & +6.5 \\
\hline Chabazite & -104.8 & -110.0 & +5.2 \\
\hline Omega & -98.8 & -103.4 & +4.6 \\
\hline NaK-L & -101.5 & -107.4 & +5.9 \\
\hline NaK-P1 & -102.4 & -107.0 & +4.6 \\
\hline ZK-5 & -103.5 & -108.6 & +5.1 \\
\hline NaK-chabazite & -104.4 & -109.5 & +5.1 \\
\hline Na-mordenite & -105.7 & -112.1 & +6.4 \\
\hline Ferrierite & -105.9 & -110.5 & +4.6 \\
\hline ZSM-11 & -105.0 & -113.0 & +8.0 \\
\hline ZK-4 & -106.1 & -110.7 & +4.6 \\
\hline ZSM-5 & -106.0 & -112.0 & +6.0 \\
\hline ZSM-35 & -108.0 & -113.0 & +50 \\
\hline TMA-Sodalite & -110.5 & -116.2 & +5.7 \\
\hline & & & \\
\hline
\end{tabular}


Estimation of the ${ }^{29} \mathrm{Si}$ chemical shift of $(\mathrm{Si}-\mathrm{O})_{3} \mathrm{Si}-\mathrm{Al}$. Recognizing that replacement of $-\mathrm{OSi}$ by $-\mathrm{Al}$ in $\mathrm{R}_{3} \mathrm{Si}-\mathrm{OSi}$ (where $\mathrm{R}=$ alkyl) to yield $\mathrm{R}_{3} \mathrm{Si}-\mathrm{Al}$, as reflected in the reported ${ }^{29} \mathrm{Si}$ chemical shift ${ }^{15}$ of $\left[(t-\mathrm{Bu})_{3} \mathrm{Si}\right]_{2} \mathrm{Al}-\mathrm{Al}\left[(t-\mathrm{Bu})_{3} \mathrm{Si}\right]_{2}$, the $29 \mathrm{Si}$ chemical shift of a $\mathrm{SiO})_{3} \mathrm{Si}-\mathrm{Al}$ moiety can be estimated as about $-100 \mathrm{ppm}\left(\right.$ for $\left.(\mathrm{SiO})_{3} \mathrm{Si}-\mathrm{OSi}\right)+20=-80$ ppm.

Five-Coordinate Aluminum Structures. Regarding structural types IV to VI, in which an aluminum atom is connected to three oxygen atoms of the silica surface, one might question the possibility of formation of this kind of structure. The following picture is a top-down representation of five-coordinate aluminum species on a $\beta$-cristobalite $<111>$ face. This surface is commonly used as a model for single silanols on a silica surface. ${ }^{16}$

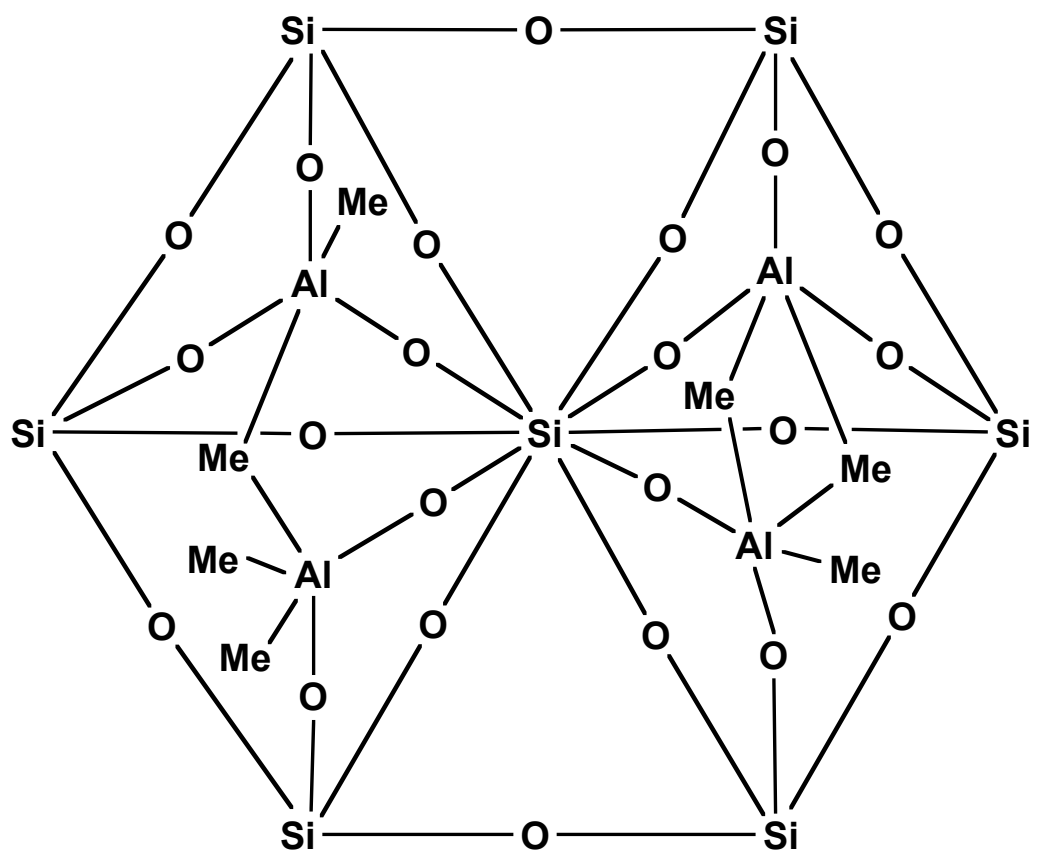


The normal interatomic distances represented in the above picture are: ${ }^{17-25} \mathrm{Si}-\mathrm{Si}=5.04$ $\AA, S i-O=1.60 \AA, A l-O=1.78 \AA$ and $A l-C=1.97 \AA$.

From geometrical considerations, it appears that formation of the five-coordinate structures of types I, II and III, each of which has two surface oxygen atoms attached to each aluminum atom, should be favorable. Five-coordinate structures of types IV, V and $\mathrm{VI}$, in which three oxygen atoms of silica are attached to an individual aluminum atom, would likely be very strained, because the possible positions of the aluminum atom are restricted by three surface $\mathrm{Si}-\mathrm{O}-\mathrm{Al}$ linkages and by the shared- $\mathrm{CH}_{3}$ linkage. The left part of the picture above simulates the geometry of a type-V structure and the right part of the figure simulates the geometry of a type- $\mathrm{VI}$ structure. The $\mathrm{C}-\mathrm{Al}-\mathrm{C}$ angle in the $\mathrm{Al}-\left(\mathrm{CH}_{3}\right)_{2}-\mathrm{Al}$ bridge (right part of the picture) is about $84.4^{\circ}$, which is a strained angle compared to the $\mathrm{C}-\mathrm{Al}-\mathrm{C}$ angle $\left(102^{\circ}\right)$ in the $\mathrm{Al}\left(\mathrm{CH}_{3}\right)_{3}$ dimer ${ }^{25}$ but this might still be possible to form. On the basis of only the ${ }^{27} \mathrm{Al}$ spectra, all of the above structures (type I through type VI) are possible; we cannot at this time distinguish among them by just a simple ${ }^{27} \mathrm{Al}$ MAS spectrum.

The ${ }^{13} \mathrm{C}$ relaxation results concluded that the surface methyl groups in $\mathrm{Al}\left(\mathrm{CH}_{3}\right)_{\mathrm{n}}$ moieties are relatively immobile. ${ }^{26,27}$ This characteristic might due to $\mathrm{Al}-\mathrm{CH}_{3}-\mathrm{Al}$ bridges formed on the surface. Thus, among the five-coordinate aluminum structures proposed above, types II, III, V and VI are likely to be the $\mathrm{Al}\left(\mathrm{CH}_{3}\right)_{\mathrm{n}}$ species responsible for the most intense signal in ${ }^{13} \mathrm{C}$ spectrum $(-12 \mathrm{ppm})$, and these types of structure manifest the $\mathrm{Al}-\mathrm{CH}_{3}-\mathrm{Al}$ bridging characteristics. 


\section{Hypothetical Processes}

Formation of Six-Coordinate Aluminum Species.

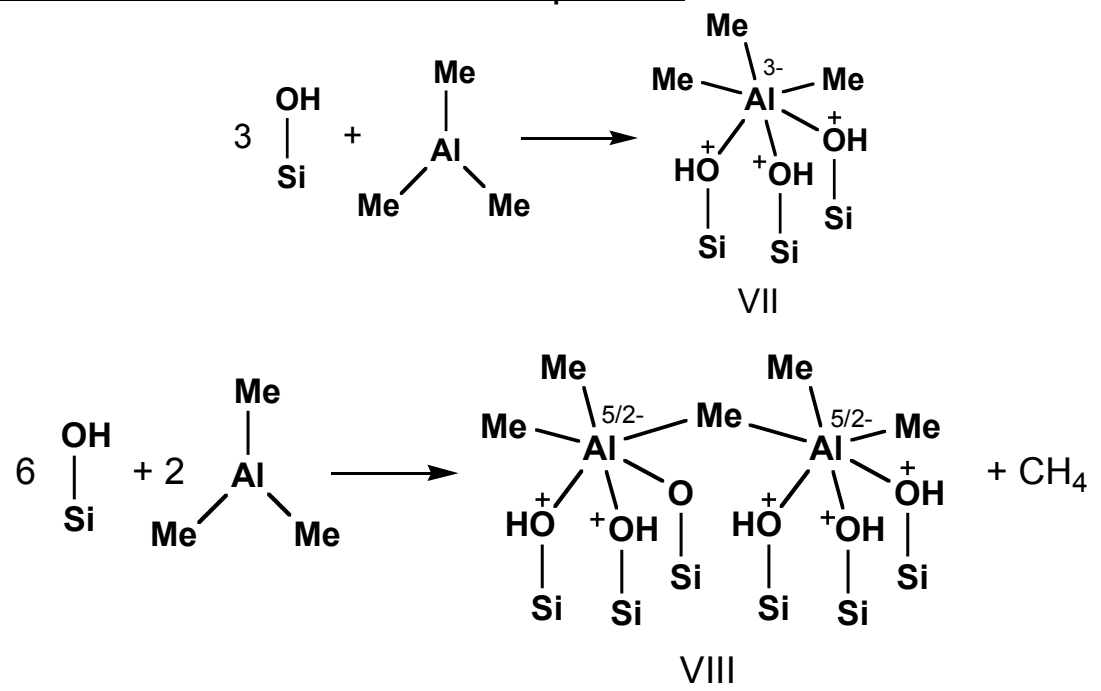

Formation of Four-Coordinate Aluminum Species.

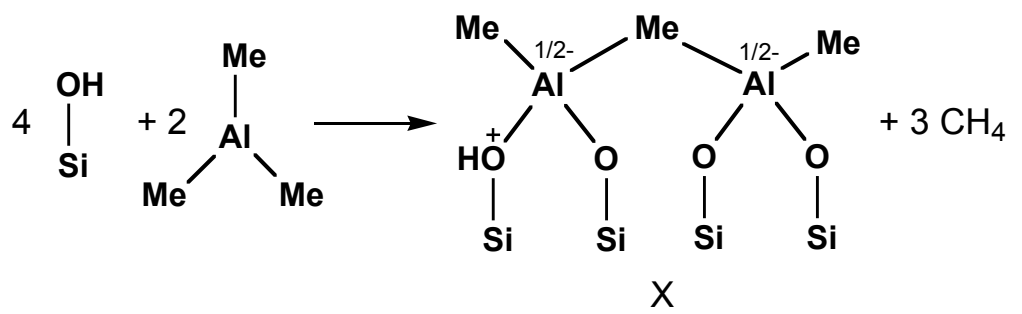



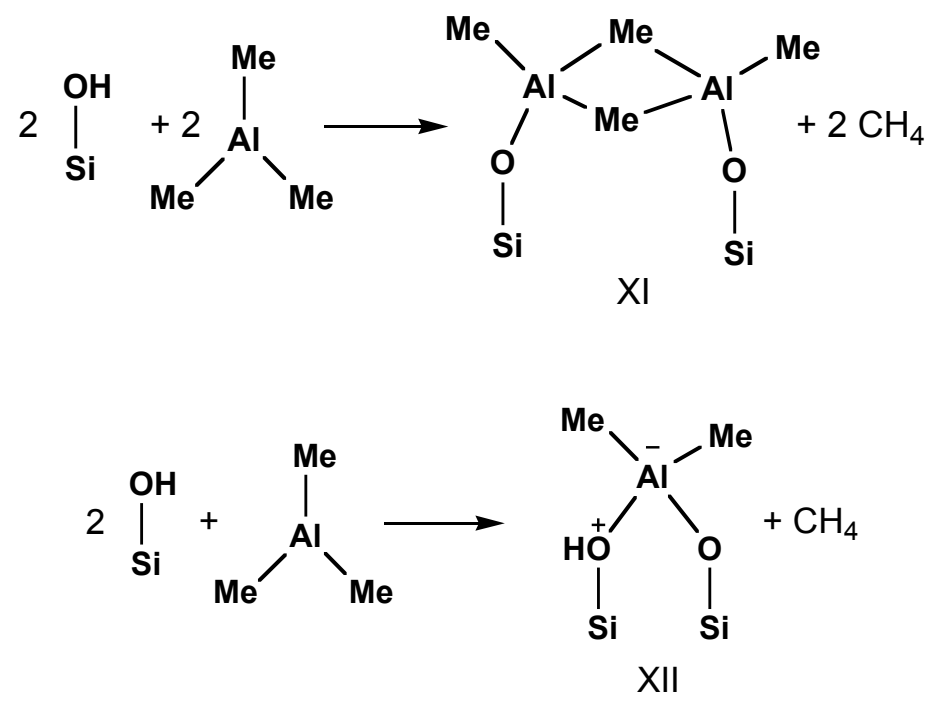

Hypothetical Reactions of Diethyl Ether with Five-Coordinate Aluminum Species.
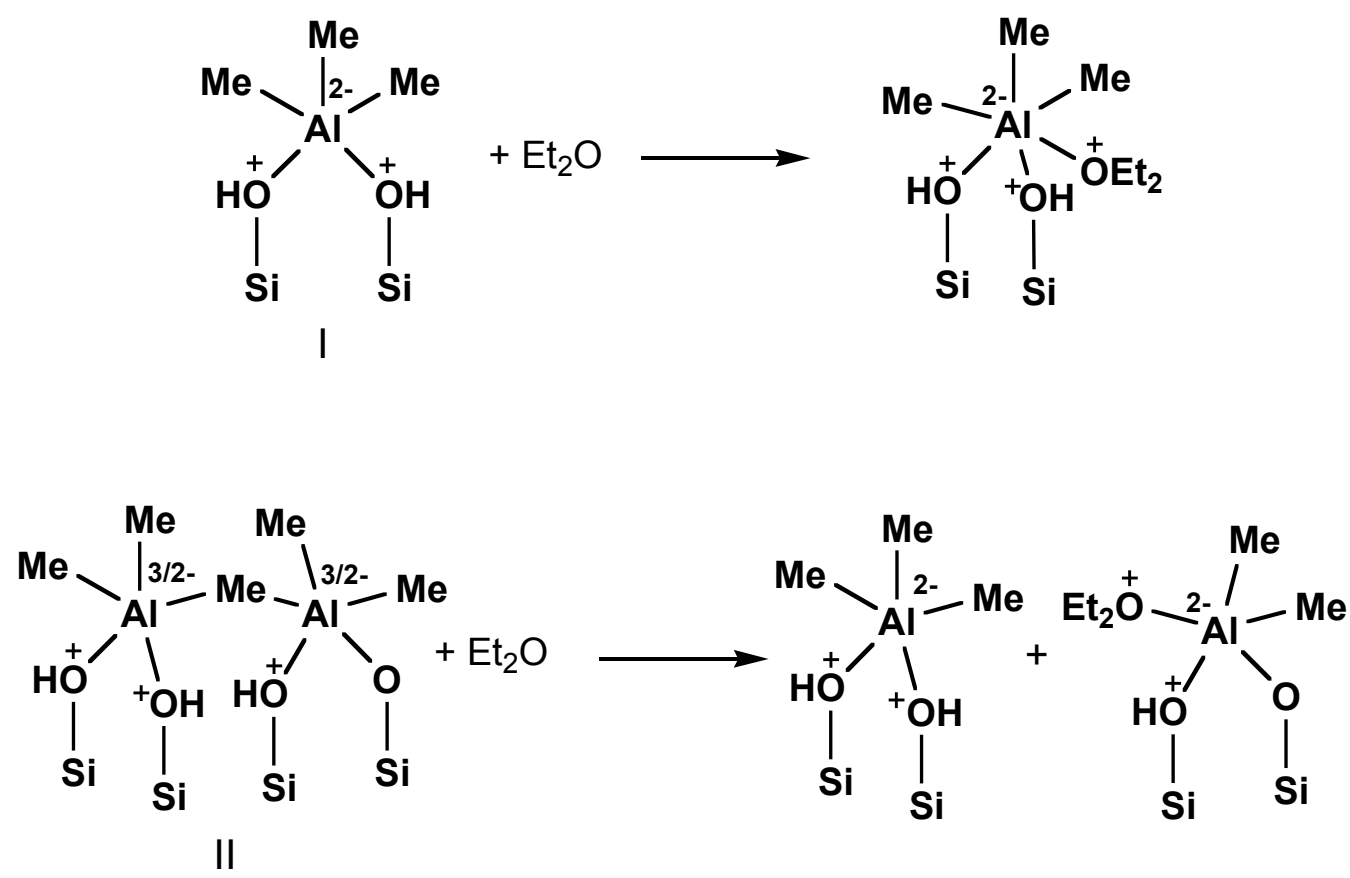

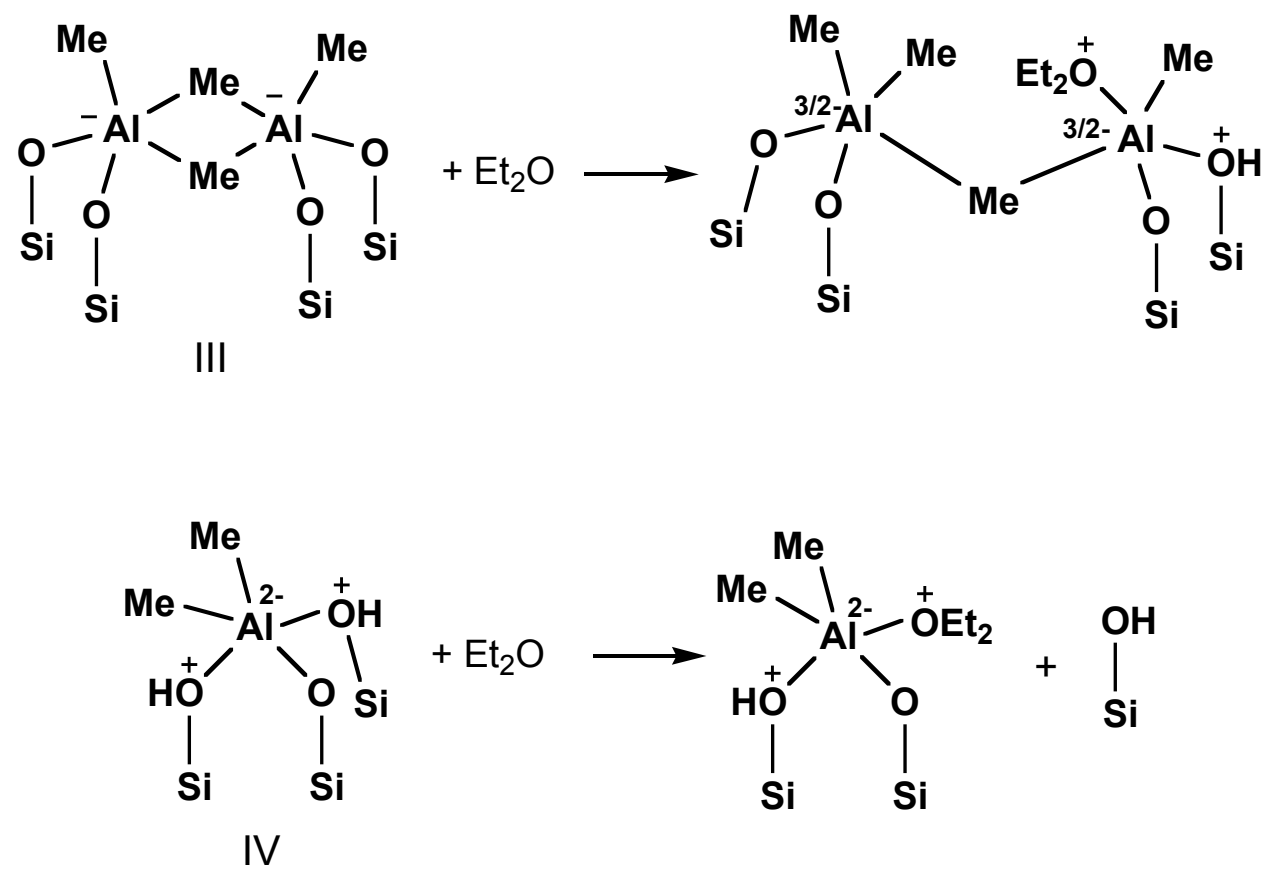

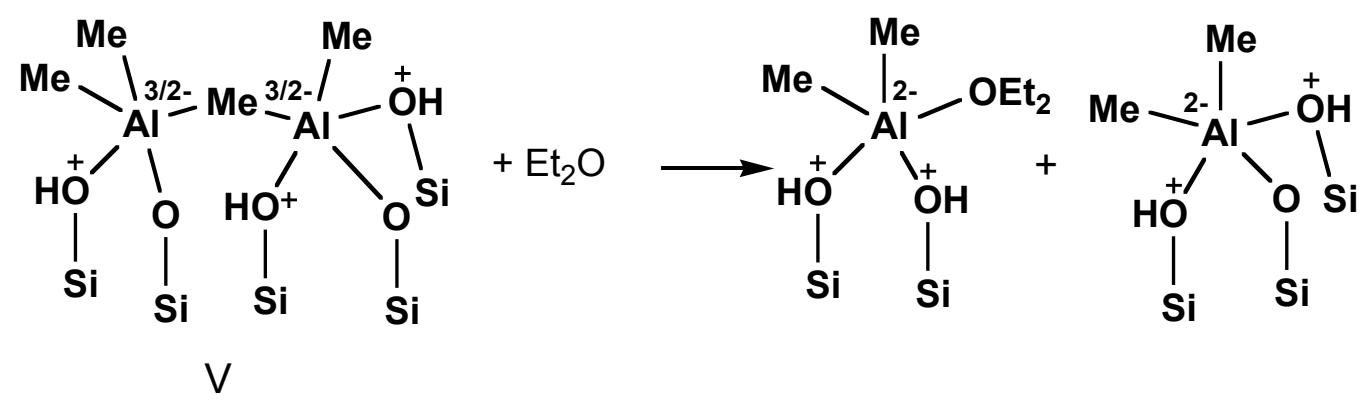

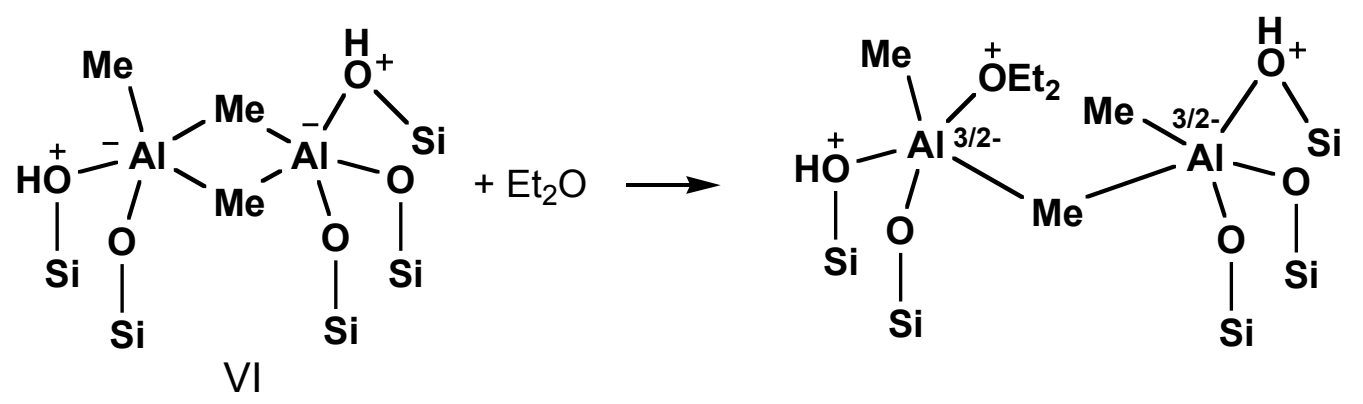

Hypothetical Reactions of Diethyl Ether with Six-Coordinate Aluminum Species 


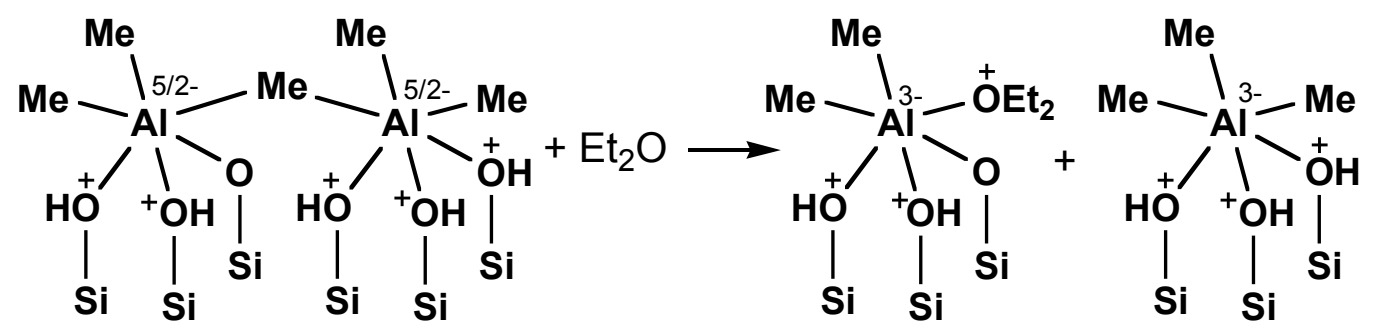

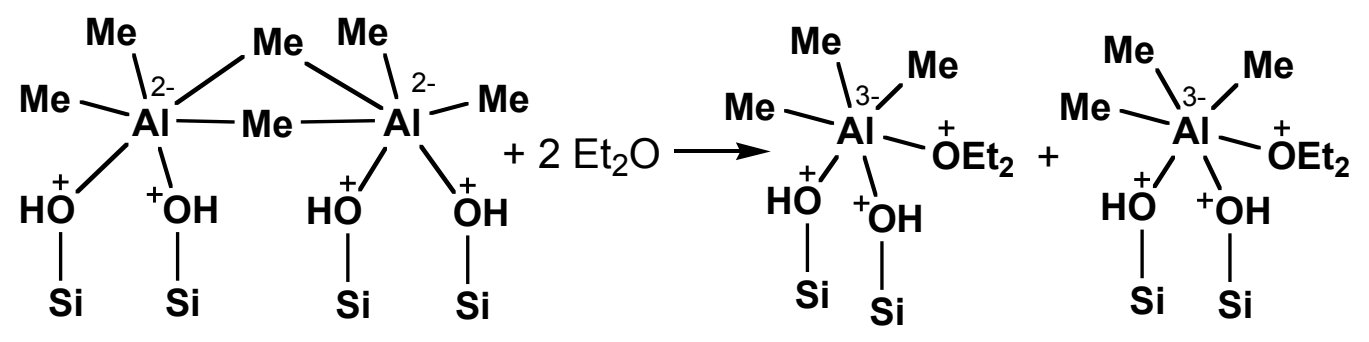

Hypothetical Reactions of Diethyl Ether with Four-Coordinate Aluminum Species.

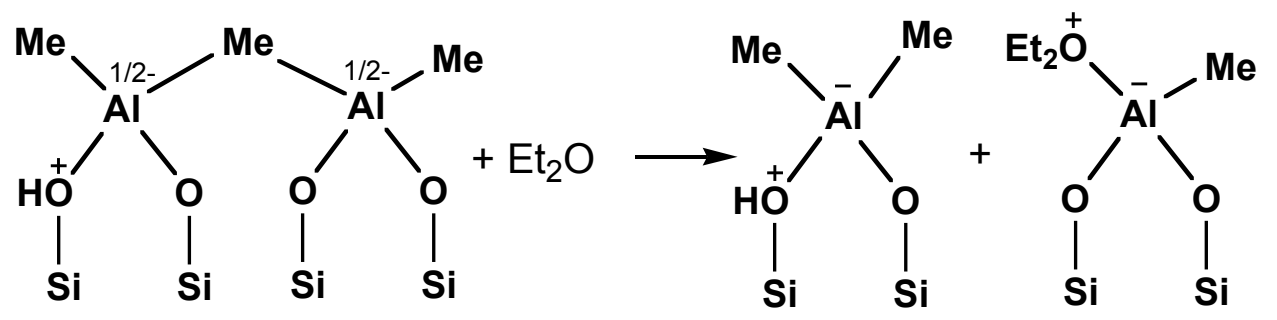<smiles>CCO[Al-](C)(C)[Al-]O[Si](C)(C)O[Al](C)(C)O[Si](C)(C)O[Si](C)(C)O[Si]</smiles>

Hypothetical Reactions of Water with Five-Coordinate Aluminum Species. 

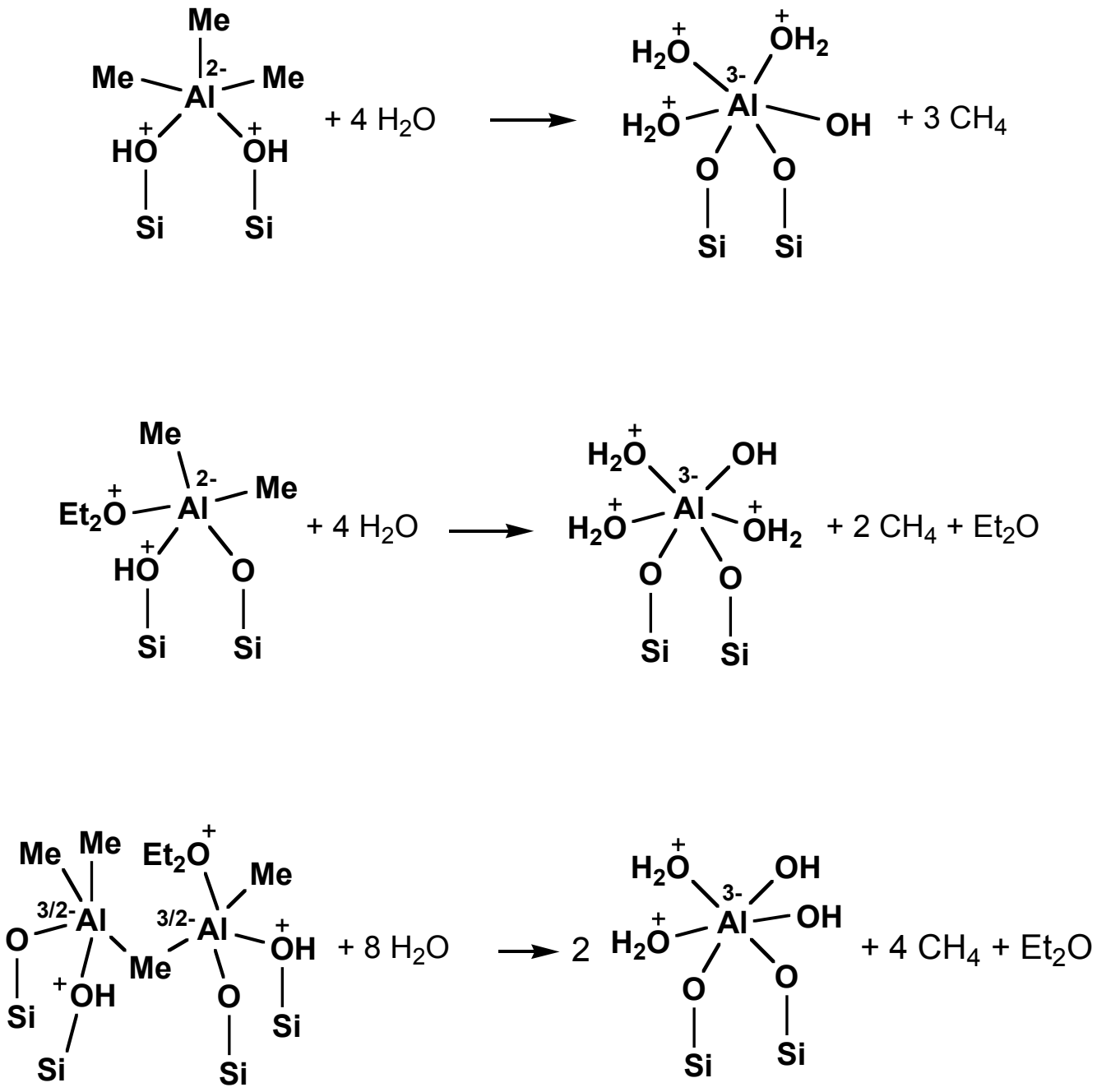

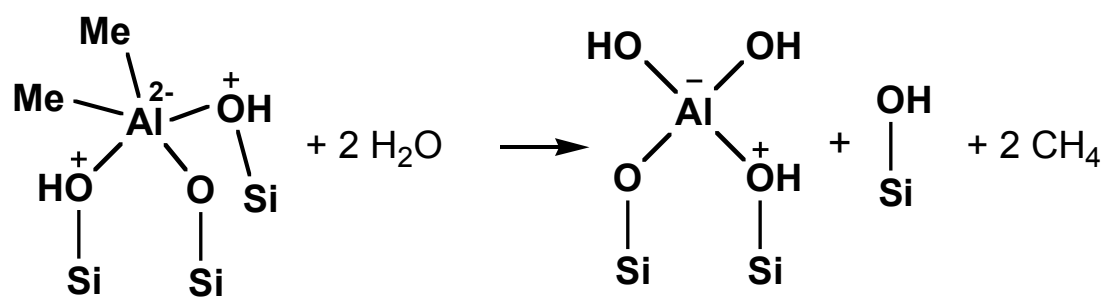




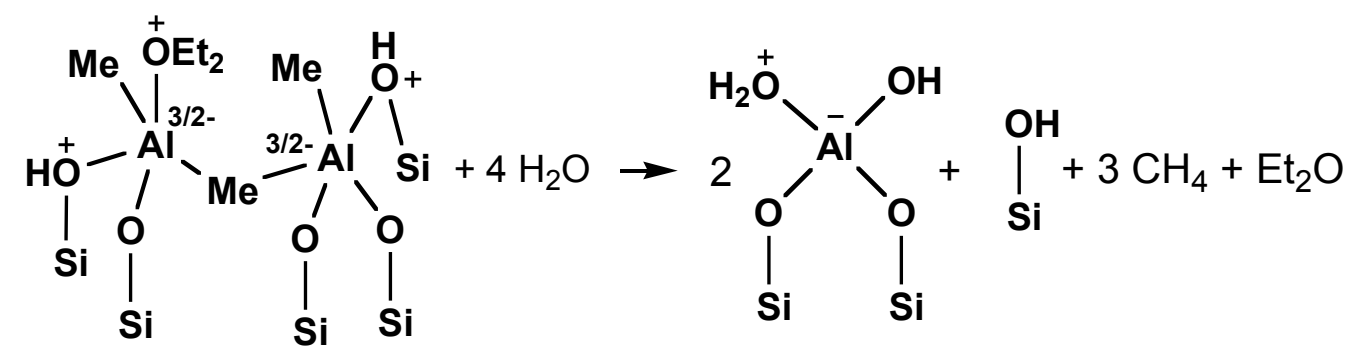

Hypothetical Reactions of Water with Six-Coordinate Aluminum Species.

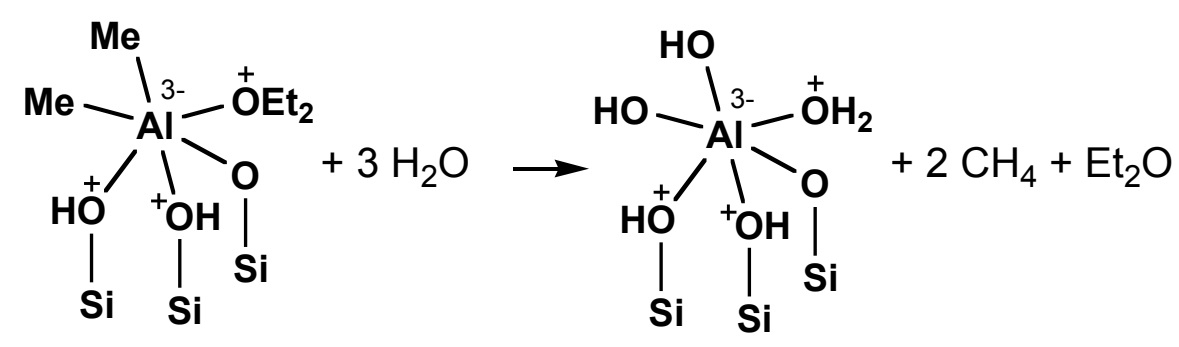

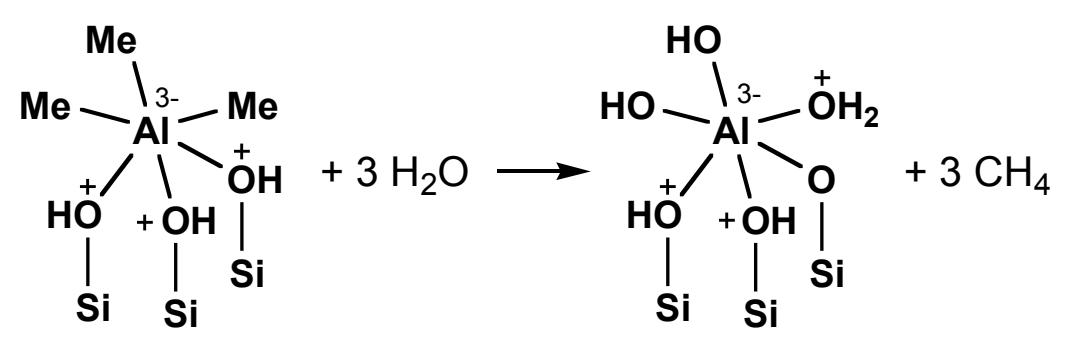

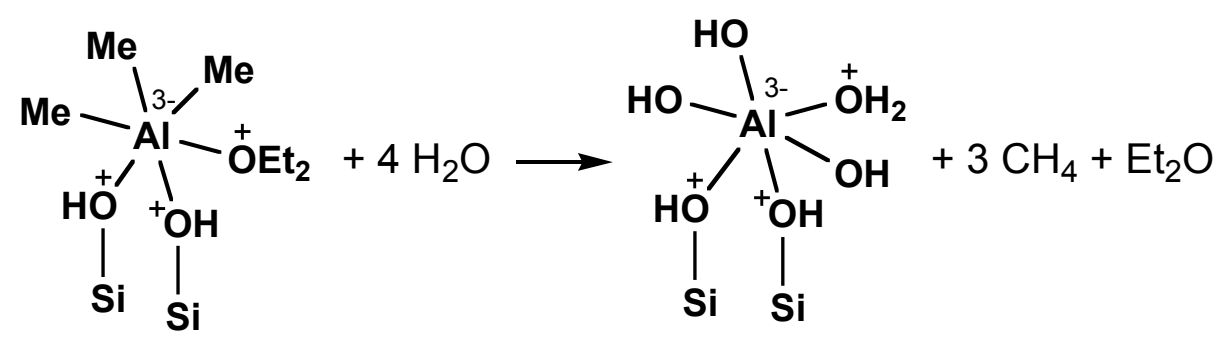

Hypothetical Reactions of Water with Four-Coordinate Aluminum Species. 

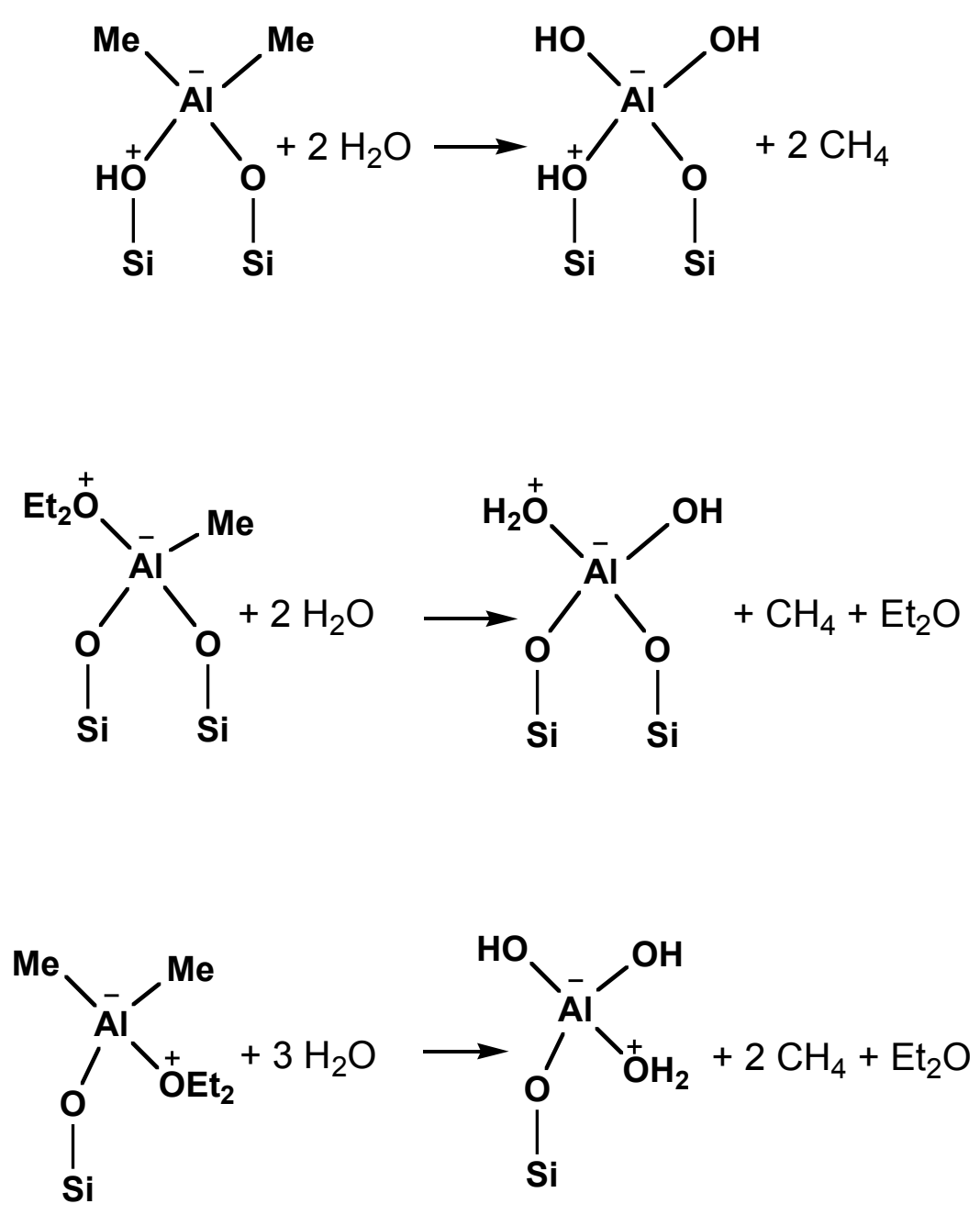


\section{Supporting Information References}

1. $\quad$ Pines, A.; Gibby, M. G.; Waugh, J. S., Chem. Phys. Lett. 1972, 15, 373.

2. Maciel, G. E.; Sindorf, D. W., J. Am. Chem. Soc. 1980, 102, 7606.

3. Sindorf, D. W.; Maciel, G. E., J. Am. Chem. Soc. 1981, 103, 4263.

4. $\quad$ Sindorf, D. W.; Maciel, G. E., J. Am. Chem. Soc. 1983, 105, 3767.

5. Chuang, I. S.; Kinney, D. R.; Maciel, G. E., J. Am. Chem. Soc. 1993, 115, 8695.

6. Chuang, I. S.; Maciel, G. E., J. Am. Chem. Soc. 1996, 118, 401.

7. Maciel, G. E.; Chuang, I. S., Surfactant Science Series 2006, 131, 425.

8. $\quad$ Gore, K. U.; Abraham, A.; Hegde, S. G.; Kumar, R.; Amoureux, J.-P.; Ganapathy, S., J. Phys. Chem. B 2002, 106, 6115.

9. Samoson, A.; Lippmaa, E., Physical Review B: Condensed Matter and Materials Physics 1983, 28,6567 .

10. Liu, C. C.; Maciel, G. E., J. Am. Chem. Soc. 1996, 118, 5103.

11. Wang, X.; Coleman, J.; Jia, X.; White, J. L., J. Phys. Chem. B 2002, 106, 4941.

12. Breitmaier, E.; Voelter, W., ${ }^{13}$ C NMR spectroscopy: methods and applications. Verlag Chemie: Weinheim, Bergstr., 1974; p 51.

13. Ganapathy, S.; Schramm, S.; Oldfield, E., J. Chem. Phys. 1982, 77, 4360.

14. Stejskal, E. O.; Memory, J. D., High resolution NMR in the solid state: fundamentals of CP/MAS. Oxford University Press: New York, 1994; Vol. I Introduction to NMR Principles 3, p 111.

15. Wiberg, N.; Amelunxen, K.; Blank, T.; Nöth, H.; Knizek, J., Organometallics 1998, 17, 5431.

16. Chuang, I. S.; Maciel, G. E., J. Phys. Chem. B 1997, 101, 3052.

17. Atwood, J. L.; Hunter, W. E.; Crissinger, K. D., J. Organomet. Chem. 1977, 127, 403.

18. Hobbs, J. D.; Cygan, R. T.; Nagy, K. L.; Schultz, P. A.; Sears, M. P., Am. Mineral. 1997, 82,657 .

19. Liu, W.; Hassan, A.; Wang, S., Organometallics 1997, 16, 4257.

20. Thomson, K. T.; Wentzcovitch, R. M.; McCormick, A.; Davis, H. T., Chem. Phys. Lett. 1998, 283, 39.

21. Gutierrez, G.; Johansson, B., Physical Review B: Condensed Matter and Materials Physics 2002, 65, 104202/1. 
22. Turney, J. M.; Sari, L.; Yamaguchi, Y.; Schaefer, H. F., III, J. Chem. Phys. 2005, 122, 094304/1.

23. Baur, W. H., Acta Crystallographica, Section B: Structural Crystallography and Crystal Chemistry 1977, B33, 2615.

24. Dove, M. T.; Keen, D. A.; Hannon, A. C.; Swainson, I. P., Phys. Chem. Miner. 1997, 24, 311.

25. Nyfeler, D.; Armbruster, T., Am. Mineral. 1998, 83, 119.

26. DiVerdi, J. A.; Li, J.; Maciel, G. E., J. Phys. Chem. To be submitted. 2006.

27. Li, J. M.S. Thesis, Colorado State University, Fort Collins, Colorado, 2006. 